\title{
COMPETENCE AND COMPELLABILITY OF WIVES AT COMMON LAW
}

\section{"So Great a Favourite is the Female Sex of the Laws of England"}

In April this year the House of Lords delivered their opinions in the case of Hoskyn v. Commissioner of Police for the Metropolis. 2 The point of law which arose for consideration was whether a wife is a compellable witness against her husband in a case of violence against her by him. In this case the accused was charged with wounding Janis Ann Scrimshaw with intent to do grievous bodily harm. Two days before the trial the accused married the woman who he had assaulted. At the trial Mrs. Hoskyn (as she then was) did not wish to give evidence against her husband but ordered to tesify by the judge on the basis that $R$. v. Lapworth ${ }^{3}$ was a correct statement of the common law. Lapworth decided that a wife was not only a competent witness at a husband's trial when he was charged with a crime of violence against her but that she could be compelled to give evidence for the prosecution. In Hoskyn the accused was convicted at trial and he appealed utimately to the House of Lords. ${ }^{4}$ The House held by a majority 5 that a wife, although competent at common law, is not a compellable witness. After a careful review of the common law the majority that a wife, although competent at common law, is not a compellable witness. After a careful review of the common law the majority rejected the argument at a wife's competence at common law automatically involved compellability. Lord Wilberforce said: 6

\begin{abstract}
... our task is to ascertain and state the law as it is. We may and must both respect any decision and course of practice as evidence of what the law is, and we must try to understand the policy, which may be an evolving policy, behind the common law, but if a decision or course of practice is contrary to the common law, as, in relation to $R$. v. Lapworth the appellant argues that it is, we must so declare.?
\end{abstract}

This case is of interest because the House of Lords' declaration of the common law resulted in the overruling of $R$. v. Lapworth, a decision which has found support in some Canadian provinces, notably in Alberta where it was recently applied.8 Coincidentally the effect of

1. Backstone's Commentaries on the Laws of England, (1765) Book 1, Ch. XV, 445. The subsection applies to both husband and wife but as the wife has been the reluctant witness in the majority of the decided cases I will speak of the wife's rights.

2. [1978] 2 All E.R. 136. [1978] 2 W.L.R. 695.

3. [1931] 1 K.B. 117.

4. The Court of Appeal, Criminal Division dismissed the appeal (unreported) considering itself to be bound by $R$. v. Lapworth.

5. Lord Edmund-Davies dissenting.

6. [1978] 2 All E.R. 136 at 138.

7. But see, Lord Edmund Davies id. at 152: "a declaration of what, in the opinion of this House, the law is will be largely influenced by the individual views of your Lordships recording what should be the law."

8. R. v. Lonsdale (1973) 15 C.C.C. (2d) 201 (Alta. A.D.). 
Hoskyn is to endorse a British Columbia Provincial Court interpretation of the common law ${ }^{9}$ which was disapproved in the Alberta decision. ${ }^{10}$

The House of Lords overruled Lapworth because, on a close examination of the common law rule that a wife is a competent witness at her husband's trial when he was charged with crimes of violence against her, the majority of the House found that this variety of common law competency did not include compellability." Avory J., in delivering the judgment of the Court of Criminal Appeal in Lapworth, stated: 12

Once it is established that (the wife) is a competent witness it follows that she is a compellable witness.

This statement was rejected by the House of Lords. As Lord Wilberforce said 13 in reply to a question which might have been asked of the House of Lords in Leach v. The King: 14

And if they had been asked: 'What about the case where a wife was competent at common law? Does not the ordinary rule make her compellable?' they would surely have answered: 'No, because the considerations ${ }^{5}$ which led the law to treat her as a competent do not in any way weaken the force of the principle we have stated that a wife ought not to be forced into the witness box, a principle of general application and funadmental importance.

The majority of the House of Lords based their declaration of the common law primarily on dicta from the Leach case, especially Lord Atkinson's statement:16

The principle that a wife is not to be compelled to give evidence against her husband is deep seated in the common law of this country....

Nevertheless in Canada the wife has been forced into the witness box.

The relevant statutory provision in Canada is section $4(4)$ of the Canada Evidence Act ${ }^{17}$ which provides:

9. R. v. Carter (1970) 5 C.C.C. 155 (B.C. Prov. Ct.).

10. Both these decisions were cited by Lord Wilberforce in Hoskyn, supra $\mathrm{n}$. 6 at 143 although the citation there of $R$. v. Carter as (1976) 28 C.C.C. (2d) 219 is incorrect.

11. Common law authorities reviewed by the House included Coke's Commentaries on Littleton (1628), Hale's History of Pleas of the Crown (1800), Hawkin's Pleas of the Crown (1824) and Blackstone's Commentaries (1765). Loró Wilberforce states that "None of these authorities or any authority until the 19th century deals with the question of compellability where the wife is competent." Supra n. 6 at 139. Nevertheless the House was content to rest its decision primarily upon the obiter assertions as to the common law by the House of Lords in Leach v. The King.

12. [1931] 1 K.B. 117 at 122.

13. Supra n. 6 at 142.

14. [1912] A.C. 305. This case formed the basis of the decision in R. v. Carter, supra n. 9 in which the provincial judge declined to follow Lapworth.

15. The wife is normally the only witness: without her evidence crimes of personal violence by the husband against her could possibly go unpunished.

16. [1912] A.C. 305 at 311. This passage was cited in Hoskyn by Lord Wilberforce, supra n. 6 at 141, Viscount Dilhorne at 146 and by Lord Salmon at 151. Lord Edmund-Davies at 157 commented that the passage "was based on no cited authority and that it was unnecessary for the determination of the only issue in that case...".

17. R.S.C. 1970, c. E-10. 
Nothing in this section affects a case where the wifel8 or husband of a person charged with an offence may at common law be called as a witness without the consent of that person.

This subsection is virtually identical to the equivalent English legislation ${ }^{19}$ and preserves the common law rule that a wife could testify against her husband in cases of personal violence by the husband against the wife. The law has been summarized by one writer as follows: 20

In cases within the common law exception the spouse is not only a competent witness for the prosecution but like any other competent witness also a compellable one. $R$. v. Lapworth.

This proposition was rejected by the British Columbia Provincial Court in $R$. v. Carter. ${ }^{21}$ The husband was charged with assault occasioning actual bodily harm and the wife did not wish to give evidence. In holding that the wife was not compellable, Provincial Judge Arkell stated:22

Avory $\mathrm{J}$. in the Lapworth decision . . . states that every competent witness is a compellable witness and draws no distinction between competence and compellability. I am satisified that the common law was correctly stated in Leach v. Director of Public Prosecutions, which draws a clear distinction between competency and compellability, a distinction clearly recognized by Parliament when enacting s.4 of the Canada Evidence Act.

The learned judge did not specifically point out that Leach v. The King was based on statutory interpretation whereas the Court of Appeal in Lapworth were concerned with the common law alone. The important point was that the judge in $R$. v. Carter was willing to draw a distinction between competence and compellability when a wife was competent at common law to give evidence against her husband.

$R$. v. Carter was disapproved by the Alberta Court of Appeal in $R$. v. Lonsdale. ${ }^{23}$ Sinclair J. A. in giving the judgment of the Court stated:24

With great respect for the learned provincial Judge and for the learned trial Judge in the present case, I do not share their view that as regards offences involving violence against a spouse the common law drew a clear distinction between competence and compellability. That type of offence was not before the House of Lords in the Leach case. Indeed it seems to me, with respect, that the common law is correctly stated in the Lapworth case. The reasoning of Avory J. in $R$. v. Lapworth is, I am persuaded, similar to that of Davies J. in Gosselin v. King 25 although that case was not one dealing with violence against a spouse.

18. The ambit of "wife" does not include "common law wives" and accordingly they are competent and compellable to testify against their "common law husbands". See Coffin v. The Queen (1955) 21 c.R. 333 (Que. Q.B.). See also Ex. p. Cote (1971) 5 C.C.C. (2d) 49 (Sask. C.A.) revg. 3 C.C.C. (2d) 383 sub nom $R e$ Cote (Sask. Q.B.) where an Indian "common law wife" was held to be competent and compellable to testify against her "common law husband".

19. Criminal Evidence Act 1898, 61 \& 62 Vict., c.36, s.4(2).

20. P.K. McWilliams, Canadian Criminal Evidence (1974), 555.

21. (1970) 5 C.C.C. 155.

22. Id. at 159 .

23. (1973) 15 C.C.C. (2d) 201.

24. Id. at 207.

25. (1903) 33 S.C.R. 255. In fact Avory J. sought to distinguish competence conferred by statute from competence at common law whereas Davies J. drew an analogy lat 276) between nineteenth century English evidence statutes and the Canada Evidence Act 1893 in order to establish compellability under the statute. Nowhere in his decision did Davies J. refer to the competence of wives at common law to testify against their husbands and like Avory J. he brushed aside the argument that compellability could be a separate concept from competence. It was this very reasoning which enabled a wife to be a compellable witness against her husband charged with murder, which is not the law today. See also Lord Salmon's comments infra. 
Gosselin preceded Leach and was not cited in the later case. Both decisions turned on statutory interpretation. The majority of the Supreme Court found that section 4 of the Canada Evidence Act $1893^{26}$ made a wife a compellable witness for the prosecution where the husband was charged with murdering a third person. Three years later the law was changed by Parliament.2i In Leach the House of Lords found that a similar statute ${ }^{28}$ conferring competency on wives could not confer compellability without expressly stating so in the Act. In the light of Leach and of section $4(2)$ of the Canada Evidence Act 29 which specifically enumerates the cases where a wife shall be both competent and compellable for the prosecution, it is submitted that the remarks in Gosselin as to competence and compellability of wives are of doubtful authority today. Whether or not it is eventually accepted in Canada that Lapworth is based on an erroneous interpretation of the common law, the case does have significant policy considerations of its own. In 1931 Dean Weir wrote: 30

In Canada it has been the practice in many magisterial courts to treat the wife in such cases as a competent, but not compellable, witness for the prosecution against her husband. Cases are frequently reported in the press in which a wife who has laid a charge against her husband for an offence involving injuries to her person, has later had a change of heart and has refused to give evidence when the time came. In such cases, if the prosecution is dependent on the spouse's evidence, the magistrate, probably with reluctance because he realizes that the wife's change of attitude may have been brought about by the "kicks and kisses" or curses of her husband, has frequently considered himself as having no power to compel the recalcitrant wife to give evidence and has dismissed the case. If the decision of the Court of Criminal Appeal in the Lapworth case is sound the wife can, in future, be compelled to give evidence against her husband in any case in which the offence charged involves directly an attack upon her person or liberty and that too, in cases not falling within the enumeration of offences in sub-section 2 of section 4 of the Canada Evidence Act wherein the spouse is expressly declared competent and compellable at the instance of the prosecution.

Dean Weir concluded that the remarks of Swift J. interjected during the argument in Lapworth had 'great weight': "I cannot see why the State should allow a woman to be half-killed and should have her story if she chooses to give it and should not have it if she does not choose to give it. It is not a mere quarrel between husband and wife but a crime against the peace." 31 In Hoskyn, Lord Salmon took a contrary view: 32

26. C. 31, s. 4: "Every person charged with an offence, and the wife or husband, as the case may be, of the person so charged, shall be a competent witness. ..."

27. Canada Evidence Act, 1906, c. 10, s. 1, now Canada Evidence Act, R.S.C. 1970, c. E-10, s. 4(1). "Every person charged with an offence, and, except as otherwise provided in this section, the wife or husband as the case may be is a competent witness for the defence. ..."

28. P.K. McWilliams, supra n. 20 at 533 states: "The spouse of the accused is both competent and compellable as a witness for the prosecution ( under s. $4(2)$ of the Canada Evidence Act). It differs from the English Criminal Evidence Act 1898, s. 4 of which simply provides that the wife or husband may be called as a witness either for the prosecution or defence and without the consent of the person charged.'Thus Leach v. D.P.P. (1912) $7 \mathrm{Cr}$. App.R. 157 is not applicable in Canada." It is submitted that there is no reason in principle why Leach could not apply in Canada to determine the ambit of competence in s.4(1) of the Canada Evidence Act, supra n. 26.

29. R.S.C. 1970 , c. E-10.

30. R.A. Weir, "Evidence - Compellability of One Spouse as a Witness against the Other Spouse in a Criminal Prosecution." (1931) Can. Bar. Rev. 216 at 222, 223.

31. Id. at 223. The remarks of Swift J. do not appear in full in the Law Reports (1931) 1 K.B. 117 but are found in 47 T.L.R. 10.

32. Supra n. 6 at $151,152$. 
I cannot however agree with the Court of Appeal when it sought to justify the decision in Lapworth's case by saying: 'It must be borne in mind that the court of trial in circumstances such as this where personal violence is concerned . . . is not dealing merely with a domestic dispute between husband and wife, but it is investigating a crime. It is in the interests of the state and members of the public that where that is the case evidence of that crime should be freely available to the court which is trying the crime.' If such a consideration could have been a justification for the decision in Lapworth's case still more would it be a justification for making the wife a competent and compellable witness against her husband were he to be charged with murder, which clearly she is not.

The common law as declared by the House of Lords in Hoskyn allows a wife to choose whether she will testify or not in cases where her husband has committed a crime of personal violence against her. Thus in England the wife is indeed given preferential treatment which is not accorded to mortals outside the married state. Lord EdmundDavies' vigorous dissent sought to put the wife in such cases in the same position as the ordinary witness, in saying: "All competent witnesses are, virtually without exception, also compellable witnesses." 33 The dissent gives added weight to Lord Wilberforce's conclusion in his opinion. After reviewing several Commonwealth authorities, some favouring, ${ }^{34}$ some denying ${ }^{35}$ compellability, Lord Wilberforce concluded: 36

In the state of this authority it would be invidious to assert where the 'better opinion' is to be found.

In Canada, Parliament could have removed all doubt by expanding section 4(2) of the Canada Evidence Act ${ }^{37}$ thus making a spouse both competent and compellable for the prosecution whenever the other spouse was charged with a crime of violence against his or her partner. Until that happens the better opinion, it is submitted, depends upon whether the supposed foundations of the common law are to be preferred over the justice of establishing the truth in prosecutions of crimes against the peace.

R.C. Secord*

33. Id. at 153.

34. H.M. Advocate v. Commelin [1836] 1 Swinton's Justiciary Reports 291 (Scotland), Sharp v. Rodwell [1947] Vict. L.R. 82 at $85, R$. v. Lonsdale (1973) 15 C.C.C. (2d) 201 (Alta. A.D.). Lord Wilberforce, supra n. 6 at 143, also referred to the article by Dean Weir (1931 Can. Bar Rev. 216).

35. Riddle v. The King (1911) 12 C.L.R. 622, $R$. v. Phillips [1922] S.A.S.R. 276. $R$. v. Carter, supra n. 9.

36. Supra n. 6 at 143.

37. R.S.C. 1970,c.E-10.

* B.A. University at Durham, Barrister-at-law, Gray's Inn; LL.M. Candidate at the University of Alberta. 